\title{
A COMPARATIVE STUDY OF THE CREATININE CLEARANCE IN 12-HOUR AND 24-HOUR TIMED URINE COLLECTION IN HEALTHY VOLUNTEER
}

\author{
Raj Kumar Yadav, Binod Yadav and Anitha Devanath
}

\begin{abstract}
Introduction: The kidneys remove creatinine, which is produced at a constant rate as a result of muscle metabolism, from the blood. Like insulin, creatinine is filtered, but neither reabsorbed nor secreted by the kidneys. Thus, the creatinine clearance test, which compares a patient's blood and urine creatinine concentrations, can also be used to calculate the GFR. Therefore, a single measurement of plasma creatinine levels provides a rough index of kidney function.
\end{abstract}

Aims and Objective: To compare the creatinine clearance in 12- hour and 24- hour timed urine collection in healthy volunteer.

Materia and Methods: 50 Healthy volunteers are selected. 25 volunteers were male and 25 volunteers were female. Each volunteer was given 2 cans for urine collection. The first can is used for 12 hour collection study from $7 \mathrm{am}$ to $7 \mathrm{pm}$ on day 1 and the second can for another 12 hour collection from $7 \mathrm{pm}$ to $7 \mathrm{am}$ on day 2. The samples were mixed well and measured the volume separately. Five $\mathrm{ml}$ of sample from the first can was transferred to the can 2 and again mixed well. The creatinine is measured by using modification of the jaffe reaction.

Resu t: The person's correlation between 12-hour and 24- hour urine samples showed a significant correlation in both males and females $(r=0.8$ and 0.6 respectively, $p$ values $<0.05)$

Conc usion: This is clinical acceptable and hence $12 \mathrm{hr}$ urine collection can be adopted in patients who are well hydrated and it can replace 24-hr urine collection.

Keywords: Creatinine Clearance, GFR, Healthy Volunteers

\section{Introduction}

Creatinine clearance has became the standard laboratory method to determine glomerular filteration rate. This value is derived mathematically relating the serum creatinine concentration to the urine creatinine excreated during a period of time, usually 24hour. Elevated creatinine concentration is associated with abnormal renal function, especially as it relates to glomerular function.
Creatinine is a nearly ideal substance for the measurement of clearance. $t$ is endogeneously metabolic product and cleared essentially through glomerular filteration . $\mathrm{t}$ is not reabsorbed and is only slightly secreted by the proximal tubule). ${ }^{1,2}$

Creatinine is produced endogeneously and .released into the body fluid at a constant rate and is plasma levels are maintained within narrow limits, it renal clearance is measured 
as an indicator of GFR. ${ }^{3}$

GFR is usually accepted as the best overall index of kidney function in health and disease.

Normal GFR varies according to age, sex, and body size; in young adults it is approximately $120-130 \mathrm{~mL} / \mathrm{min} / 1.73 \mathrm{~m} 2$ and declines with age. A decrease in GFR precedes the onset of kidney failure; therefore a persistently reduced GFR is a specific diagnostic criterion for CKD. Below $60 \mathrm{~mL} / \mathrm{min} / 1.73 \mathrm{~m} 2$, the prevalence of complications of CKD increases, as does the risk of cardiovascular disease. $^{4}$

GFR cannot be measured directly. The urinary clearance of an ideal filtration marker, such as inulin, iothalamate or iohexol, is the gold standard for the measurement of GFR. This is cumbersome in clinical practice and serum levels of endogenous filtration markers, such as creatinine, have traditionally been used to estimate GFR. ${ }^{4}$

\section{Materia and method}

This study was carried out in the Department of Clinical Biochemistry, St. John Medical College Hospital, Bangalore, during the period of 2008-2009. The objectives of the study were to compare the Creatinine clearance in 12-hour and 24-hour timed urine collection in healthy volunteer and to assess whether 12-hour urine collection can replace 24-hour urine collection. To fulfill the objectives 50 Healthy volunteers, 50 male and 50 females, were selected based on inclusion criteria. Subjects with renal dysfunction and any other conditions with increased Serum and urine creatinine were excluded from the study. Each volunteer was given 2 cans for urine collection. The first can is used for 12 hour collection study from $7 \mathrm{am}$ to $7 \mathrm{pm}$ on day 1 . The second can was used for another 12 hour collection study from $7 \mathrm{pm}$ to $7 \mathrm{am}$ on day 2. The samples were mixed well and the volume was measured separately for both cans. Five $\mathrm{ml}$ of sample from the first can was transferred to the can 2 and again mixed well.

The creatinine is measured by using modification of the kinetic Jaffe reaction ${ }^{5}$ using Dimension Clinical chemistry system Flex reagent cartridge from Siemens Company. Creatinine is generally regarded as the most useful endogenous substance to measure for the assessment of kidney function ${ }^{6}$.

\section{Princip e}

$\mathrm{n}$ the presence of a strong base such as $\mathrm{NaOH}$, lithium picrate reacts with creatinine to form a red chromophore. The rate of increasing absorbance at $510 \mathrm{~nm}$ due to the formation of this chromophore is directly proportional to the creatinine concentration in the sample and is measured using a bichromatic $(510,600 \mathrm{~nm})$ rate technique. Bilirubin is oxidized by potassium ferricyanide ${ }^{7}$ to prevent interference.

\section{Statistica Ana ysis}

The samples were analyzed statistically by using paired sample' $t$ ' test. The pearson's correlation was done to evaluate if there was correlation between the samples. 


\section{Resu t}

Tab e 1 : Descriptive statistic of Creatinine $C$ earance

\begin{tabular}{|c|c|c|c|c|c|c|c|c|c|c|}
\hline & \multirow{3}{*}{$\begin{array}{r}12-\mathrm{h} \\
\text { Creatinine } \\
\text { Clearance } \\
\text { Mean } \\
\end{array}$} & \multicolumn{2}{|c|}{$\begin{array}{l}24 \mathrm{hr} \\
\text { creatinine } \\
\text { clearence }\end{array}$} & \multirow{3}{*}{$\begin{array}{r}95 \% \mathrm{C} . \\
\text { Lower } \\
\text { bound }\end{array}$} & \multirow{3}{*}{$\begin{array}{l}\text { Mean } \\
\text { Upper } \\
\text { bound }\end{array}$} & \multirow{3}{*}{ S.D } & \multirow{3}{*}{ S.E } & \multirow{2}{*}{\multicolumn{2}{|c|}{$95 \%$ C. }} & \multirow[b]{3}{*}{$\begin{array}{l}\text { Upper } \\
\text { bound }\end{array}$} \\
\hline & & S.D & S.E & & & & & & & \\
\hline & & & & & & & & & $\begin{array}{l}\text { Lower } \\
\text { bound }\end{array}$ & \\
\hline $\begin{array}{c}\mathrm{Cr} \mathrm{Cl} \\
\text { for all } \\
\text { samples }\end{array}$ & 88.5 & 9.0 & 1.3 & 89.3 & 97.3 & 101 & 11.4 & 1.6 & 103.6 & 112.3 \\
\hline $\begin{array}{c}\mathrm{Cr} \mathrm{Cl} \text { in } \\
\text { males }\end{array}$ & 93 & 9.7 & 1.9 & 89.3 & 97.3 & 108 & 10.5 & 2.1 & 103.6 & 112.3 \\
\hline $\begin{array}{l}\mathrm{Cr} \mathrm{Cl} \text { in } \\
\text { Females }\end{array}$ & 83.7 & 4.8 & 1.0 & 81.8 & 85.8 & 95.3 & 8.4 & 1.6 & 91.9 & 98.9 \\
\hline
\end{tabular}

depicts the descriptive statistics for Creatinine females) and also genderwise. Table2

Clearance for all the samples (both males and

Tab e 2 : Comparison of groups for Creatinine $C$ earnce for 12-h and 24-h urine co ection

\begin{tabular}{|c|c|c|c|c|c|c|}
\hline & \multirow{2}{*}{$\begin{array}{c}\text { Mean } \\
\text { difference }\end{array}$} & \multirow[b]{2}{*}{$\mathrm{SD}$} & \multirow[b]{2}{*}{$\mathrm{SE}$} & $95 \% \mathrm{C}$. & \multirow{2}{*}{$\begin{array}{c}\text { 'p' value } \\
\text { Upper } \\
\text { bound }\end{array}$} & \\
\hline & & & & $\begin{array}{l}\text { Lower } \\
\text { bound }\end{array}$ & & \\
\hline $\begin{array}{l}\mathrm{CrCL} 12 \mathrm{hr} \text { and } \\
\mathrm{CrCl} 24 \mathrm{hr} .\end{array}$ & -13.09 & 7.84 & 1.109 & -15.3 & -10.9 & $<0.001$ \\
\hline $\begin{array}{l}\text { CrCL } 12 \mathrm{hr} \text { and } \\
\mathrm{CrCl} 24 \mathrm{hr} \text { Male }\end{array}$ & -14.61 & 8.42 & 1.68 & -18.1 & -11.1 & $<0.001$ \\
\hline $\begin{array}{c}\text { CrCL } 12 \mathrm{hr} \text { and } \\
\mathrm{CrCl} 24 \mathrm{hr} \text { Female }\end{array}$ & -11.56 & 7.05 & 1.41 & -14.5 & -8.6 & $<0.001$ \\
\hline
\end{tabular}

*SD signifies standard deviation

*SE signifies standard error.

\section{Discussion}

depicts the mean difference, standard deviation and standard error with $95 \%$ Confidence nterval. The pearson's correlation between $12-\mathrm{h}$ and 24-h urine samples showed a significant correlation in both males and females $(\mathrm{r}=0.8$ and 0.6 respectively, $\mathrm{p}$ values $<0.05$ )
The creatinine clearnce was found to be lower in 12-h urine collection in comparison to 24-h urine collection. The diurnal variation is not incorporated if the urine collection period were to be reduced from $24-\mathrm{h}$ to $12-\mathrm{h}$. This is appropriately depicted in our study. There is a significant correlation between 12-h and 24-h 
urine collection. There is a difference of approximately $15 \%$ in creatinine clearance between 12-h and 24-h urine samples.

f circumstance of specimen collection are not defined and controlled, variability in values for an individual 12 hour and 24 hour clearance can be expected. Rates of glomerular filtration and creatinine excreation $^{8}$

The results of the study are very similar to previous studies. Baumann TJ et al in their study on 10 critically ill patients for accurate determination of creatinine clearance has shown that an 8-h urine collection is acceptable if the deviation is $20 \%$ from the 24-h value. $\mathrm{n}$ their study, they have shown that the mean difference between each 2-h interval and 24-h interval were not significantly different. Clearance values determined from 8- and 12-h collections were within $20 \%$ of the $24-\mathrm{h}$ urine creatinine clearance. ${ }^{9}$

Another study by Roberti Riera E et al studied 30 children for creatinine clearance in 3 - and 24-h urine collection. The study showed no significant difference in these two different timed urine collections. $\mathrm{n}$ their study they have recommended that 3 -h urine collection can be adopted if the patients are adequately hydrated and hospitalized patients especially infants or young children. ${ }^{10}$

Richardson James in his study has showed that there is no significant difference in onehour creatinine clearance and 24-hour creatinine clearance. ${ }^{11}$

\section{Conc usion}

$\mathrm{n}$ this study the creatinine clearance is significantly different in urine sample collected over $12 \mathrm{hr}$ period and $24 \mathrm{hr}$ period in both male and female but the difference is about $15 \%$ between the two timed collections. This is clinical acceptable and hence $12 \mathrm{hr}$ urine collection can be adopted in patients who are well hydrated and it can replace $24-\mathrm{h}$ urine collection

\section{References}

1. Hood B, Attman PO, Ah men J, Jagenburg R. Renal hemodynamics and limitation of creatinine clearance in determining filteration rate in glomerular disease. Scand Urol Nephrol 1971;5:154-161.

2. Car A.Burtis, Edward R. Ashwood, David E. Burns. Tiet $\mathbf{z}$ Fundamental of clinical chemistry, 4th edition.

3. Maack, T., Johnson, V., Kan , S.T., et a . Renal filteration transport and metabolism of low molecular weight protiens: A review, kidney nt., $1979 ; 16: 251-270$.

4. Dr.Prafu B. Godkar, Dr. Darshan P. Godkar. Textbook of medical laboratory technology., 2003; $2^{\text {nd }}$ edition: $324-325$

5. Larsen K. Creatinine assay by a reaction- Kinetic approach, Clin Chem Acta 1972;41:209-217.

6. Tietz NW. Textbook of Clinical Chemistry, W.B. Saunder Co., Philadelphia, PA 1994, p 1531 ( utility of creatinine ) and pp 58-69 ( specimen collection and storage recommendation)

7. Knapp ML and Mayne PD. Development of an automated kinetic Jaffe method designed to minimize bilirubin interference in plasma creatinine assays, Clin Chem Acta 1987;168:239246

8. Camera AA, Arn KD, Reimer A, et a. The twenty-four hourly endogenous cratinine clearance as a clinical measure of the functional state of the kidneys. J Lab Clin Med 1971;37:743-763.

9. Bauman $\mathbf{T} \mathbf{J}$, Staddon $\mathbf{J} \mathbf{E}$, Horst $\mathbf{M}$ and Bivins B A. Minimum urine collection periods for accurate determination of creatinine clearance in critically ill patients. Clin Pharm. 1987 6(5): 3938. 
10. Robert Riera E, de A meida-Rego Fitho E, Dos Santos - Coimbra M, Ve asquez Jones L, Gordi o Paniagua G, Betancourt Monzn C. Comparison between the 3- and 24- hour urine collection for cratinine clearance .Bol Med Hosp

11. James A. Richardson, MD, and Peter E, Phi ibin, MD. The One Hour Creatinine Clearance Rate in Healthy Men. Jama, 1971;216:987-990.

Address of Correspondence: $M r$. Ra Kumar Yadav, Lecturer, Department of Biochemistry, Gandki Medical College, Pokhara, Nepal. E-mail: yadav.raazu.raj2@gmail.com 